\title{
STRATEGI PENGUATAN PENDIDIKAN KARAKTER ISLAM
}

\author{
Oleh: \\ H. Abd. Wahid HS1 \\ Email: abdwahidhs06@gmail.com
}

\begin{abstract}
The essence of Islamic education is character education. Islam views and teaches morality is more important than the glory of science. Islamic education asserts that virtue values are the content of Islamic education. The content of Islamic education is character or value. Value education emphasizes the importance of the process of awareness that humans need that value to improve their spiritual quality and life. Strengthening is done by various strategies such as: integration in the learning process, habituation, exemplary, joint movements and become a priority scale for the formation of mentality and human resources in Indonesia in the future. The emphasis of learning should be done as a process of directing and developing individuals in the process of realizing the importance of character and values in shaping their self and spiritual qualities.
\end{abstract}

Keywords: strategy, strengthening, education, Islamic character

\section{Pendahuluan}

Esensinya pendidikan Islam adalah pendidikan karakter. Islam memandang dan mengajarkan kemualiaan akhlak lebih penting dibandingkan dengan kemuliaan ilmu pengetahuan. Karakter menjadi peletak dasar jiwa dan kepribadian individu, yang menjadi dasar utama dalam pengembangan pendidikan Islam. Pendidikan Islam mengatur secara mendalam bagaimana membentuk karakter individu yang berhubungan dengan Tuhan, interaksi dengan manusia, lingkungan, bahkan dalam hubungan dengan bangsa dan negara.

Karakter menjadi hal yang sangat penting dalam pencapaian hasil belajar dalam Islam, berupa internalisasi nilai-nilai dasar dalam diri

${ }^{1}$ Dosen Program Studi Pendidikan Bahasa Arab STAI Syaichona Moh. Cholil Bangkalan Madura. 
individu. Penguatan karakter Islami bertujuan untuk menginternalisasikan nilai Islam dalam perubahan cara berpikir, bersikap, dan bertindak menjadi lebih baik. Nilai-nilai utama karakter Islam sejalan dengan penguatan nilainilai dalam pendidikan karakter dalam kebijakan pendidikan nasional seperti: nilai religius, nasionalis, mandiri, gotong royong, integritas. Nilainilai ini ingin ditanamkan dan dipraktikkan agar diketahui, dipahami, dan diterapkan di seluruh sendi kehidupan di sekolah dan di masyarakat.

Penguatan Pendidikan Karakter Islami lahir karena kesadaran akan tantangan ke depan yang semakin kompleks dan tidak pasti. Pendidikan karakter yang dilandasi oleh nilai-nilai agama, akan menjadi semakin kuat karena agama menjadi pedoman dan pembentukan nilai-nilai utama dalam penanaman nilai-nilai karakter. Hal ini menuntut lembaga pendidikan untuk mempersiapkan peserta didik secara keilmuan dan kepribadian, berupa individu-individu yang kokoh dalam nilai-nilai moral, spiritual dan keilmuan. Memahami latar belakang, urgensi, dan konsep dasar pengautan karaketr Islam menjadi sangat penting bagi pengembang pendidikan Islam agar dapat menerapkannya sesuai dengan konteks dalam satuan pendidikan masing-masing. Hal ini juga dipandang sebagai sesuatu yang mendesak untuk dilaksanakan. Terutama untuk menjawab berbagai persoalan bangsa terkait dengan kemerosotan berbagai nilai-nilai dalam kehidupan bermasyarakat, berbangsa, dan bernegara.

\section{Penguatan Karakter Islami dalam Pendidikan Formal}

Pada esensinya karakter merupakan watak, sifat, kepribadian, akhlak atau budi pengerti yang menjadi ciri khas seseorang atau sekelompok orang. ${ }^{2}$ Karakter secara lebih mendasar merupakan nilai-nilai perilaku manusia yang berhubungan dengan Tuhan Yang Maha Esa, diri sendiri, sesama manusia, lingkungan, dan kebangsaan yang terwujud dalam pikiran, sikap, perasaan, perkataan, dan perbuatan berdasarkan normanorma agama, hukum, tata-krama, budaya dan adat-istiadat. ${ }^{3}$

2 Departemen Pendidikan Nasional. 2008. Kamus Besar Bahasa Indonesia. Jakarta: Pusat Bahasa. Hlm 219.

${ }^{3}$ Azimabadi Badr. 2000. Ettiquettes of Islamic Life. Kuala Lumpur: Adam Publisher \& Distibutiors. Hlm 4. 
Pendidikan karakter dalam Islam, dapat dipahami sebagai upaya penanaman kecerdasan kepada anak didik dalam berpikir, bersikap, dan berperilaku sesuai dengan nilai-nilai luhur yang menjadi jati dirinya, diwujudkan dalam interaksi dengan Tuhannya, diri sendiri, antarsesama, dan lingkungannya sebagai manifestasi hamba dan khalifah Allah. ${ }^{4}$

Berbagai kalangan menyerukan dan menggiatkan implementasi pendidikan karakter di Indonesia. Termasuk juga elemen Islam dalam mengembangkan sistem pendidikan di Indonesia. Esensinya karakter pendidikan Islam sejalan dan saling mendukung dengan pengembangan penguatan pendidikan karakter yang dikembangkan dalam sistem pendidikan di Indonesia.

Dalam konteks karakter, pendidikan Islam menitikberatkan fungsinya pada pengembangan individu untuk mengenal diri sendiri dan lingkungan sehingga mampu beradaptasi serta mengembangkan kreativitas dan produktivitas. Pendidikan karakter Islam, berfungsi untuk mengembangkan dan melestarikan nilai-nilai insan yang akan menuntun diri manusia, baik secara individu maupun sosial. ${ }^{5}$

Pemahaman tentang pentingnya penguatan karakter belum cukup kuat di kalangan pendidik. Selain itu kurangnya guru memahami apa dan bagaimana pendidikan karakter yang dikembangkan, serta bagaimana cara dan strategi penerapannya dalam pembelajaran. Pada umumnya mereka memahami pendidikan karakter secara parsial, belum menyentuh pendidikan karakter seperti yang dicita-citakan bersama. Integrasi pendidikan karakter Islam dalam pembelajaran masih belum banyak dilakukan, hanya sekedar tempelan semata.

Dalam kenyataannya, guru masih banyak mengembangkan dan menekankan aspek penguasaan konsep dalam pembelajarannya. Tidak mudah mengatur dan menyajikan pembelajaran dengan penguatan pendidikan karakter. Tetapi, harus dilakukan mengingat, urgensi tentang

${ }^{4}$ Purwanti, Eni, dkk. 2014. Pendidikan Karakter: Menjadi Berkarakter MuslimMuslimah Indonesia. Surabaya: Kopertais Wilayah IV Surabaya. Hlm 5.

5 Achmadi. 2010. Ideologi Pendidikan Islam. Yogyakarta: Pustaka Pelajar. Hlm 35. 
pentingnya pendidikan karakter. Pentingnya mengembangkan platform pendidikan nasional yang meletakkan pendidikan karakter Islam sebagai jiwa utama dengan memperhatikan keberagaman budaya Indonesia dan merevitalisasi serta memperkuat potensi dan kompetensi dunia pendidikan di Indonesia.

Pendidikan karakter adalah suatu sistem penanaman nilai-nilai karakter kepada warga sekolah yang meliputi komponen pengetahuan, kesadaran atau kemauan, dan tindakan untuk melaksanakan nilai-nilai tersebut, baik terhadap Tuhan Yang Maha Esa (YME), diri sendiri, sesama, lingkungan, maupun kebangsaan sehingga menjadi manusia insan kamil. Penguatan Pendidikan Karakter merupakan suatu sistem penanaman nilainilai karakter kepada warga sekolah yang meliputi komponen pengetahuan, kesadaran atau kemauan, dan tindakan untuk melaksanakan nilai-nilai tersebut. Penguatan dilakukan dengan berbagai gerakan bersama dan menjadi skala prioritas bagi pembentukan mentalitas dan sumber daya manusia Indonesia ke depan.

Tujuan pendidikan karakter Islami adalah menjadikan anak didik sebagai hamba dan khalifah Allah yang berkualitas taqwa. Pekerjaan atau aktivitas takwa meliputi semua bidang mulai dari persoalan keyakinan hidup, ibadah yang menghubungkan manusia yang lemah dengan Tuhannya yang Maha Kuat, moralitas, aktivitas interaksi sosial, cara berfkir, hingga gaya hidup.

Indikator-indikator orang-orang berkualitas takwa dalam al-Qur'an dijelaskan sebagai berikut. ${ }^{6}$

1. Memiliki keyakinan yang membara, keyakinan yang kuat bahwa Allah berkuasa atas segala sesuatu (QS 2 :3).

2. Memiliki perspektif jangka panjang. Kebiasaan memandang jauh kedepan sehingga menjadi pribadi proaktif (QS 59 : 18).

3. Memiliki obsesi dan cita-cita yang sangat tinggi. Barambisi menjadi orang yang bisa mendapat anugerah ilmu dan harta, lalu seluruhnya didayagunakan di jalan kebaikan yang akan mengantarkannya pada ridho Allah Swt (QS 2 : 218)

${ }^{6}$ Purwanti, Eni, dkk. 2014. Pendidikan Karakter: Menjadi Berkarakter MuslimMuslimah Indonesia. Surabaya: Kopertais Wilayah IV Surabaya. Hlm 6. 
4. Memiliki speed dalam berprestasi, selalu mengejar mutu pada semua aspek kepribadian. Keunggulan dan kesempurnaan selalu menjadi standar dalam meningkatkan kualitas diri, sehingga peluang besar menuju kesuksesan akan dapat diraih (QS 3 : 153, QS 5 : 48)

5. Selalu berobsesi menjadi yang terdepan, siap memasuki medan kompetisi dalam kebaikan secara secara sehat dan konstruktif. Orangorang yang menjadikan dunia sebagai sarana mengabdi dan mendekat kepadanya serta berbuat kebaikan kepada sesama, orang yang bertakwa tidak layak bekerja, berusaha, berprestasi seadanya tanpa greget, tanpa target, dan tanpa kualitas tinggi (QS 5:48, QS 23:61)

6. Menggunakan waktu secara efektif dan produktif. Membiasakan bekerja dengan tingkat efisiensi, efetifitas, dan produktifitas yang tinggi. Meninggalkan segala perkataan dan tindakan yang tidak bermanfaat (QS 23 : 1 dan 3).

7. Memiliki semangat kolektif dan kolaboratif. Kebersamaan, sinergi dan harmoni menjadi watak kehidupan sebagaimana alam ini diciptakan.

Penguatan Pendidikan Karakter Islam di sekolah dilakukan untuk membentuk siswa memiliki karakter mulia, sesuai dengan nilai-nilai Islam. Karakter mulia berarti individu memiliki pengetahuan tentang potensi dirinya, yang ditandai dengan nilai-nilai seperti reflektif, percaya diri, rasional, logis, kritis, analitis, kreatif dan inovatif, mandiri, hidup sehat, bertanggung jawab, cinta ilmu, sabar, berhati-hati, rela berkorban, pemberani, dapat dipercaya, jujur, menepati janji, adil, rendah hati, malu berbuat salah, pemaaf, berhati lembut, setia, bekerja keras, tekun, ulet/gigih, teliti, berinisiatif, berpikir positif, disiplin, antisipatif, inisiatif, visioner, bersahaja, bersemangat, dinamis, hemat/efisien, menghargai waktu, pengabdian/dedikatif, pengendalian diri, produktif, ramah, cinta keindahan (estetis), sportif, tabah, terbuka, tertib.

Beberapa nilai karakter Islami, yang relevan dengan pengembangan karakter dalam Penguatan Pendidikan Karakter di Indonesia adalah sebagai berikut. ${ }^{7}$

7 Kementerian Pendidikan dan Kebudayaan. 2015. Pembinaan Pendidikan Karakter di Sekolah Menengah Pertama. Jakarta: Kemdikbud.Hlm 8. 
1. Nilai karakter dalam hubungannya dengan Tuhan

Religius pikiran, perkataan, dan tindakan seseorang yang diupayakan selalu berdasarkan pada nilai-nilai Ketuhanan dan/atau ajaran agama Islam.

2. Nilai karakter dalam hubungannya dengan diri sendiri

a. Jujur; perilaku yang didasarkan pada upaya menjadikan dirinya sebagai orang yang selalu dapat dipercaya dalam perkataan, tindakan, dan pekerjaan, baik terhadap diri dan pihak lain

b. Bertanggung jawab; sikap dan perilaku seseorang untuk melaksanakan tugas dan kewajibannya sebagaimana yang seharusnya dia lakukan, terhadap diri sendiri, masyarakat, lingkungan (alam, sosial dan budaya), negara dan Tuhan YME.

c. Bergaya hidup sehat; segala upaya untuk menerapkan kebiasaan yang baik dalam menciptakan hidup yang sehat dan menghindarkan kebiasaan buruk yang dapat mengganggu kesehatan.

d. Disiplin; tindakan yang menunjukkan perilaku tertib dan patuh pada berbagai ketentuan dan peraturan.

e. Kerja keras; perilaku yang menunjukkan upaya sungguh-sungguh dalam mengatasi berbagai hambatan guna menyelesaikan tugas (belajar/pekerjaan) dengan sebaik-baiknya.

f. Percaya diri; sikap yakin akan kemampuan diri sendiri terhadap pemenuhan tercapainya setiap keinginan dan harapannya.

g. Berjiwa wirausaha; sikap dan perilaku yang mandiri dan pandai atau berbakat mengenali produk baru, menentukan cara produksi baru, menyusun operasi untuk pengadaan produk baru, memasarkannya, serta mengatur permodalan operasinya.

h. Berpikir logis, kritis, kreatif, dan inovatif; berpikir dan melakukan sesuatu secara kenyataan atau logika untuk menghasilkan cara atau hasil baru dan termutakhir dari apa yang telah dimiliki.

i. Mandiri; sikap dan perilaku yang tidak mudah tergantung pada orang lain dalam menyelesaikan tugas-tugas.

j. Ingin tahu; sikap dan tindakan yang selalu berupaya untuk mengetahui lebih mendalam dan meluas dari apa yang dipelajarinya, dilihat, dan didengar. 
k. Cinta ilmu; cara berpikir, bersikap dan berbuat yang menunjukkan kesetiaan, kepedulian, dan penghargaan yang tinggi terhadap pengetahuan.

3. Nilai karakter dalam hubungannya dengan sesama

a. Sadar akan hak dan kewajiban diri dan orang lain; sikap tahu dan mengerti serta melaksanakan apa yang menjadi milik/hak diri sendiri dan orang lain serta tugas/kewajiban diri sendiri serta orang lain.

b. Patuh pada aturan-aturan sosial; sikap menurut dan taat terhadap aturan-aturan berkenaan dengan masyarakat dan kepentingan umum.

c. Menghargai karya dan prestasi orang lain; sikap dan tindakan yang mendorong dirinya untuk menghasilkan sesuatu yang berguna bagi masyarakat, dan mengakui dan menghormati keberhasilan orang lain.

d. Santun; sifat yang halus dan baik dari sudut pandang tata bahasa maupun tata perilakunya ke semua orang.

e. Demokratis; cara berfikir, bersikap dan bertindak yang menilai sama hak dan kewajiban dirinya dan orang lain.

4. Nilai karakter dalam hubungannya dengan lingkungan

Peduli sosial dan lingkungan; Sikap dan tindakan yang selalu berupaya mencegah kerusakan pada lingkungan alam di sekitarnya, dan mengembangkan upaya-upaya untuk memperbaiki kerusakan alam yang sudah terjadi dan selalu ingin memberi bantuan bagi orang lain dan masyarakat yang membutuhkan.

5. Nilai kebangsaan

Cara berpikir, bertindak, dan wawasan yang menempatkan kepentingan bangsa dan negara di atas kepentingan diri dan kelompoknya.

a. Nasionalis; cara berfikir, bersikap dan berbuat yang menunjukkan kesetiaan, kepedulian, dan penghargaan yang tinggi terhadap bahasa, lingkungan fisik, sosial, budaya, ekonomi, dan politik bangsanya. 
b. Menghargai keberagaman; sikap memberikan respek/hormat terhadap berbagai macam hal baik yang berbentuk fisik, sifat, adat, budaya, suku, dan agama.

Karakter lebih menekankan kepada internalisasi sistem perilaku dan kaidah-kaidah yang dihayati dalam sikap dan implementasi perbuatan. 8 Pola perilaku ini telah tertanam dalam diri individu menjadi sistem nilai yang melekat pada konsep diri individu dalam kehidupan sehari-hari. Karakter bersifat akumulatif sepanjang hidup manusia. Pola umum karakter berkembang sesuai dengan tingkat perkembangan emosional, intelektual, dan fisiologis individu. Sehingga kemudian dari karakter inilah jiwa dan kepribadian individu melekat dalam bentuk sikap dan perilaku.

\section{Strategi Penguatan Karakter Islami dalam Pendidikan Formal}

Karakter unggul tidak hanya menyangkut karakter yang beretika, bermoral, sopan santun dan berinteraksi dengan masyarakat, tetapi menyangkut semua elemen dalam mentalitasi individu. Karakter Islam sejalan dengan karakter yang dikembangkan dalam tujuan pendidikan nasional. Penguatan karakter Islam harus senantuasa dilakukan oleh semua elemen pendidik Islam, dilakukan secara komprehensif dalam sistem pendidikan terutama pada lembaga pendidikan formal di Indonesia. Hal ini dilakukan dengan integrasi mata pelajaran Pendidikan Agama Islam, Pendidikan Kewarganegaraan, dan sekolah umum yang berciri khas keislaman di berbagai wilayah Indonesia.

Pendidikan Islam menegaskan bahwa nilai-nilai keutamaan (akhlak) merupakan isi pendidikan Islam. Isi pendidikan Islam adalah karakter atau nilai. Pendidikan nilai menekankan pentingnya proses penyadaran bahwa manusia membutuhkan nilai itu untuk meningkatkan kualitas spiritualnya dan kehidupannya. Penekanan pembelajaran hendaknya dilakukan sebagai proses mengarahkan dan mengembangkan individu dalam proses penyadaran pentingnya karakter dan nilai dalam membentuk kualitas diri dan spirtualnya.

${ }^{8}$ Ahmadi, Abu \& Salimi, Noor. 2008. Dasar-Dasar Pendidikan Agama Islam. Jakarta: Bumi Aksara. Hlm 199. 
Esensinya nilai dasar dan instrumental merupakan hal utama dalam pembentukan karakter Islam. Dalam praktik kehidupan justru nilai-nilai instrumental itulah yang banyak dihadapi oleh manusia, seperti perlunya nilai amanah, kejujuran, kesabaran, keadilan, kemanusiaan, etos kerja dan disiplin. Oleh karenanya Islam menekankan perlunya nilai-nilai tersebut harus dibangun pada diri seseorang sebagai jalan menuju terbentuknya pribadi yang tauhidi. Pendidikan Islam harus mampu membangun pembelajaran yang berorientasi pada peningkatan kapasitas nilai-nilai instrumental yang membentuk karakter manusia menjadi makhluk Tuhan. ${ }^{9}$

Dalam menjabarkan konsep nilai baik dasar maupun instrumental sebagai bagian dari pengembangan kurikulum pendidikan Islam, dapat dielaborasi dari:

1. Nilai-nilai yang banyak di sebutkan secara eksplisit dalam Al-Quran dan Hadist yang semuanya terangkum dalam ajaran akhlak yang meliputi akhlak dalam hubungannya dengan Allah, dengan diri sendiri, dengan sesama manusia, dengan alam dan makhluk lainnya.

2. Nilai-nilai universal yang diakui adanya dan dibutuhkan oleh seluruh umat manusia karena hakikatnya sesuai dengan fitrah manusia seperti: cinta damai, menghargai hak asasi manusia, keadilan, demokrasi, kepedulian sosial dan kemanusiaan.

Strategi penguatan dan pengembangan karakter Islam dapat dilakukan dengan cara sebagai berikut.

1. Aplikasi dalam materi pembelajaran

Dalam struktur kurikulum, pada dasarnya setiap mata pelajaran memuat materi-materi yang berkaitan dengan karakter. Secara subtantif, setidaknya terdapat dua mata pelajaran yang terkait langsung dengan pengembangan budi pekerti dan akhlak mulia, yaitu pendidikan Agama Islam dan Pendidikan Kewarganegaraan (PKn). Kedua mata pelajaran tersebut merupakan mata pelajaran yang secara langsung (eksplisit)

${ }^{9}$ Achmadi. 2010. Ideologi Pendidikan Islam. Yogyakarta: Pustaka Pelajar. Hlm 123. 
mengenalkan nilai-nilai, dan sampai taraf tertentu menjadikan peserta didik peduli dan menginternalisasi nilai-nilai. Integrasi pendidikan karakter pada mata-mata pelajaran mengarah pada internalisasi nilainilai di dalam tingkah laku sehari-hari melalui proses pembelajaran dari tahapan perencanaan, pelaksanaan, dan penilaian.

Materi pembelajaran khususnya Pendidikan Agama Islam diarakan untuk menumbuhkan dan menghubungkan (relate) kepekaan kepada penumbuhan karakter siswa dalam berbagai hal. Pembelajaran dapat diarahkan dengan pembentukan akhlakul karimah dengan menganalisis kasus yang relevan, mengidentifikasi nilai-nilai dalam perilaku Islam, dan meneladani kisah-kisah dalam sejarah Islam yang meliputi kisah Nabi dan Rasul, tokoh-tokoh Islam, dan sebagainya. Pada esensinya Pendidikan Agama Islam sarat dengan muatan dan materi tentang karakter, hanya saja perlu penguatan dengan pengembangan modelmodel pembelajaran inovatif dalam implementasinya. Selain itu, karakter Islam dapat dikuatkan dan diintegrasikan dalam berbagai elemen mata pelajaran lainnya secara interdisipliner, multidisipliner, dan crossdisipliner.

2. Pembiasaan (habit formation)

Pendidikan karakter merupakan upaya-upaya yang dirancang dan dilaksanakan secara sistematis untuk membantu peserta didik memahami nilai-nilai perilaku manusia yang berhubungan dengan Tuhan Yang Maha Esa, diri sendiri, sesama manusia, lingkungan, dan kebangsaan yang terwujud dalam pikiran, sikap, perasaan, perkataan, dan perbuatan berdasarkan norma-norma agama, hukum, tata krama, budaya, dan adat istiadat. Membentuk sikap, perilaku, dan karakter secara keseluruhan memerlukan pembiasaan. Pembiasaan itu dapat dilakukan dari hal-hal sederhana di lingkungan keluarga dan sekolah. Budaya-budaya yang dikembangkan dengan pembiasaan dapat membentuk mentalitas siswa ke arah yang lebih baik.

Dalam pendidikan karakter di sekolah, semua komponen (pemangku pendidikan) harus dilibatkan, termasuk komponen-komponen pendidikan itu sendiri, yaitu isi kurikulum, proses pembelajaran dan penilaian, penanganan atau pengelolaan mata pelajaran, pengelolaan 
sekolah, pelaksanaan aktivitas atau kegiatan ko-kurikuler, pemberdayaan sarana prasarana, pembiayaan, dan ethos kerja seluruh warga sekolah/lingkungan. Di samping itu, pendidikan karakter dimaknai sebagai suatu perilaku warga sekolah yang dalam menyelenggarakan pendidikan harus berkarakter.

3. Keteladanan (role model).

Membentuk karakter siswa, perlu adanya keteladanan terutama dari orang dewasa di sekitar siswa. Keteladanan ini bisa dari orang tua di lingkungan keluarga, kepala sekolah dan guru di lingkungan sekolah. Keteladanan ini dapat dimulai dari hal-hal yang sederhana yang berhubungan dengan pendidikan karakter.

4. Gerakan Bersama

Gerakan bersama dalam membentuk pengetahuan, sikap, dan kebiasaan siswa akan efektif dengan gerakan bersama dalam lingkungan sekolah secara terus-menerus. Gerakan bersama ini akan bersinergi dalam mencapai tujuan pendidikan karakter. Selain itu gerakan bersama akan efektif mengarahkan motivasi siswa dalam membentuk mentalitas dan kesadaran pembentukan serta penanaman karakter siswa.

Guru menyadari bahwa Penguatan Pendidikan Karakter merupakan suatu sistem penanaman nilai-nilai karakter kepada warga sekolah yang meliputi komponen pengetahuan, kesadaran atau kemauan, dan tindakan untuk melaksanakan nilai-nilai tersebut. Penguatan dilakukan dengan berbagai gerakan bersama dan menjadi skala prioritas bagi pembentukan mentalitas dan sumber daya manusia Indonesia ke depan.

Penguatan Pendidikan Karakter Islam dilakukan untuk memperkuat nilai-nilai perilaku yang diharapkan dengan serangkaian strategi baik dalam lingkungan keluarga, sekolah, dan masyarakat. Karakter yang relevan dengan nilai-nilai Islam yang diperkuat adalah karakter yang berhubungan dengan Allah Swt, diri sendiri, sesama manusia, lingkungan, dan kebangsaan yang terwujud dalam pikiran, sikap, perasaan, perkataan, dan perbuatan berdasarkan norma-norma agama, hukum, tata krama, budaya, dan adat istiadat.

\section{Penutup}


Pendidikan Islam menegaskan bahwa nilai-nilai keutamaan (akhlak) merupakan isi pendidikan Islam. Isi pendidikan Islam adalah karakter atau nilai. Pendidikan nilai menekankan pentingnya proses penyadaran bahwa manusia membutuhkan nilai itu untuk meningkatkan kualitas spiritualnya dan kehidupannya. Penguatan dilakukan dengan berbagai strategi seperti: integrasi dalam proses pembelajaran, pembiasaan, keteladanan, gerakan bersama dan menjadi skala prioritas bagi pembentukan mentalitas dan sumber daya manusia Indonesia ke depan. Penekanan pembelajaran hendaknya dilakukan sebagai proses mengarahkan dan mengembangkan individu dalam proses penyadaran pentingnya karakter dan nilai dalam membentuk kualitas diri dan spiritualnya. 


\section{DAFTAR PUSTAKA}

Achmadi. 2010. Ideologi Pendidikan Islam. Yogyakarta: Pustaka Pelajar.

Ahmadi, Abu \& Salimi, Noor. 2008. Dasar-Dasar Pendidikan Agama Islam. Jakarta: Bumi Aksara.

Badan Standar Nasional Pendidikan, 2005. Peraturan Pemerintah Nomor 19 Tahun 2005. Jakarta: BSNP.

Badr, Azimabadi. 2000. Ettiquettes of Islamic Life. Kuala Lumpur: Adam Publisher \& Distibutiors.

Departemen Pendidikan Nasional. 2008. Kamus Besar Bahasa Indonesia. Jakarta: Pusat Bahasa.

Kementerian Pendidikan Nasional. 2010. Panduan Pendidikan Karakter. Jakarta: Direktorat Pembinaan Pendidikan Dasar.

Kementerian Pendidikan dan Kebudayaan. 2015. Pembinaan Pendidikan Karakter di Sekolah Menengah Pertama. Jakarta: Kemdikbud.

Kementerian Pendidikan dan Kebudayaan. 2018. Panduan Penilaian Penguatan Pendidikan Karakter di Sekolah Dasar dan Sekolah Menengah Pertama. Jakarta: Kemdikbud.

Koesoema, Doni. 2010. Pendidikan Karakter: Strategi Mendidik Anak di Zaman Global. Jakarta: Grasindo

Purwanti, Eni. dkk. 2014. Pendidikan Karakter: Menjadi Berkarakter MuslimMuslimah Indonesia. Surabaya: Kopertais Wilayah IV Surabaya. 